\title{
INNATISM AND THE STOA
}

Our disagreements concern points of some importance. There is the question whether the soul in itself is blank like a writing tablet on which nothing has as yet been written - a tabula rasa - as Aristotle and the author of the Essay maintain, and whether everything which is inscribed there comes solely from the senses and experience; or whether the soul inherently contains the sources of various notions and doctrines which external objects merely rouse up on suitable occasions, as I believe and as do Plato and even the Schoolmen, and those who understand in this sense the passage in Saint Paul where he says that God's law is written in our hearts (Rom. 2:15). The Stoics call these sources Prolepses, that is fundamental assumptions or things taken for granted in advance.'

When Leibniz set out to defend the doctrine of innate ideas against the vigorous attack to which it had been subjected in Locke's Essay concerning human understanding, this is how he broached the subject. His words make it sound as if the debate was one of great philosophical significance and featured a pitched battle between two clearly and irrevocably opposed points of view on the origin of our ideas.

As the passage also shows, Leibniz was well aware that this was not the first time these issues had been aired. For him, the modern participants were following in the footsteps of the great names of antiquity. And he was quite right. Here are a couple of passages reporting some ancient views on the subject:

When a man is born he has the leading part of his soul like a piece of paper ready to be written upon. On it he writes each one of his notions. The first method of writing is by means of the senses. For on perceiving something, e.g. white, they have a memory of it once it has departed. When many memories of a similar kind have arisen then we say that they have experience: for experience is the plurality of similar presentations. Of notions some arise naturally in the aforesaid ways and undesignedly, others through our own instruction and attention. These are only called 'concepts', the others are also called 'prolepses'. Reason, in virtue of which we are called rational, is said to be completed by the age of seven. ${ }^{2}$ 
These [notions, i.e. of good and evil, of what is choiceworthy and to be avoided, of things congenial and repugnant] arise connaturally from principles intrinsic to our nature. ${ }^{3}$

The two positions set out in these passages seem very close to the pair of alternatives offered by Leibniz: the first report starts with the analogy of the blank paper, and goes on to develop a history of concept-formation that seems empiricist through and through, whereas the second bears a striking similarity to Leibniz' brief description of the innatist case.

One might expect that these two positions reflect the views of two ancient philosophers or philosophical schools engaged in vigorous combat over the issue - the ancient equivalents of Locke and Leibniz. But this is not the case at all. What is so extraordinary about these two passages is that they are accounts of one and the same philosophical school, the Stoa, which Leibniz cheerfully annexes to innatist territory. Needless to say, such perplexing and janus-faced evidence has provoked a long-lasting scholarly debate as to whether the Stoics did or did not believe in innate ideas, and over the last hundred years or so there has been intense scrutiny of many apparently relevant texts.

Now this historical debate about the ancient Stoa is obviously distinct from the original philosophical debate as to whether our ideas are innate or not. Nevertheless, there is a very important feature of the philosophical debate that could have a crucial effect on the historical question about the Stoa. There is a serious philosophical problem about how ideas, beliefs or knowledge can be innate and about exactly what it is that makes innatism incompatible with empiricism. For although many of the participants in the philosophical debate over innate ideas have written and argued as if the issues are clear enough, some of their spectators have stopped to question the alleged incompatibility between empiricism and innatism and ask exactly what all the fuss is about.

Part of the problem is that the impression of two clearly demarcated positions has always been fostered by the appeal to a vast spectrum of analogy and metaphor: the tabula rasa is perhaps the most notorious, but empiricists have also compared our minds to unfurnished rooms and dimly lit closets, while the opposition likens its innate ideas to congenital gout, invisible ink, seeds of light and sparks of fire, if not actual torches flaming in the firmament of our minds.

When the time comes to cash these metaphors, however, the claims of either side have seemed to many to lose their clarity, and as this happens the boundaries that separate the two sides also become blurred. For instance, one might challenge the innatist to explain (non-metaphorically) what he means by claiming ideas or beliefs for us of which we may not be aware: is the innate belief that $2+2=4$ that babies are said to possess a belief at all, or is it merely some sort of innate capacity to form that belief? On the other side, can the empiricist really be 
saying that the mind is as passive a thing as a blank piece of paper? Or will he instead talk of it possessing certain capacities to sort the information gained from experience? But if this is so, and if these capacities are not themselves acquired by experience, just what is it that is supposed to set empiricism and innatism at loggerheads?

Now, as long as there are such difficulties about determining the substance of the debate, there will be difficulties about writing its history. For if it is not clear why an innatist cannot also be called an empiricist, then ex hypothesi it will not always be easy to say whether a particular philosopher or group of philosophers belonged to one camp or the other, and it seems to me that the uncertainty surrounding Stoic accounts of concept-formation is a case in point: this scholarly dispute is not merely the result of the fragmented state of our evidence, but has also been fuelled by an underlying unclarity about what it would mean to describe them as innatists, however much evidence was available.

So it would be useful to tackle this scholarly debate by starting out with at least a general sketch of some of the different positions that can and have been called innatist and how one might distinguish these from empiricism. After doing this I shall in fact turn to some evidence that has been largely overlooked in the literature on this subject (as well as surveying some of the texts more normally cited) and show that once this is taken in conjunction with a more careful understanding of the difference between innatism and empiricism, the problem can be resolved.

\section{(1) Varieties of innatism}

What it means to claim that knowledge, beliefs or ideas are innate is itself partly a historical question, because much depends upon what particular philosophers have meant when they made such claims. So let me start at the very beginning with a question about Plato's theory of recollection. This question is one that superficially, at least, seems far removed from the epistemology of the Stoa: when Plato set out the first theory of innate knowledge he assumed that in a previous existence our souls had actually been conscious of the knowledge that is innate to us but on entering our bodies had forgotten it. Is this, philosophically speaking, a good move? On the face of it, the answer is no: in order to solve an epistemological problem, that of explaining how it is that we can learn a priori knowledge, Plato has recourse to a solution of absurd metaphysical expense. Why, one might ask, can he not make do with a form of innate knowledge that does not invoke the pre-existence of the soul, as Descartes, Leibniz and others have done? Perhaps we should claim that recollection is merely a metaphor. But this view is easily discredited by the fact that in the Phaedo Plato is out to prove the pre-existence of the soul, for which he needs to claim quite literally that the soul was once in 
conscious possession of its innate knowledge. In fact even in the Meno, where the emphasis is more epistemological, there is still a short argument for the eternal pre-existence of the soul. ${ }^{4}$

There is an answer to our question, but not one that is flattering to Plato: he wants the theory of recollection as opposed to any other form of innateness precisely because it necessitates a pre-existent soul (for that is what he is attempting to prove). On this view, Plato is guilty of the following charge. In both the Meno ${ }^{5}$ and the Phaedo $o^{6}$ he takes great care to point out that, in certain types of learning, the empirical input cannot account for the output, so some form of $a$ priori knowledge is required to explain the learner's achievement. At this point, however, the argument becomes considerably less careful: when it comes to specifying the nature of this innate endowment, Plato rushes into the assumption of pre-existent souls, and this is because his real interest is in the immortality of the soul. For the sake of an extra-epistemological conclusion, Plato does not stop to consider that other types of innate knowledge are possible and so the argument itself is invalid. A further result, of course, is that the proof of the immortality of the soul is question-begging.?

I wish to argue that Plato's argument for the pre-existence of the a priori knowledge is not as philosophically ill-considered as it may at first look, and that the reasons for this are important for a clearer understanding of what it means to say that ideas or knowledge can be innate. Let me start by examining the passage in the Meno where Plato decides that innate knowledge must be forgotten knowledge.

In this dialogue there is a famous passage where Socrates takes a slave boy ostensibly ignorant about geometry and, by asking a series of questions about a figure that he has drawn, gets the boy to answer correctly. Socrates insists that he is not teaching the slave boy anything: the correct answers that he has given have not been instilled by Socrates or anyone else. They were in him already; and after a lot of work these answers, which are now merely at the level of true belief, can be converted into knowledge. At the end of the questioning-session Socrates says:

"So without anyone having taught him, but through questioning, he will understand, himself recovering the knowledge from himself. ... and this recovery for himself of knowledge from himself is recollection, is it not?"

(Meno 85d3)

Why does Socrates so readily assume that the recovery of this knowledge must be recollection? One answer is that this assumption is already implicit in the use of the term 'recovery' ( $\tau \dot{o} a \dot{v} \alpha \lambda \alpha \mu \beta a ́ v \varepsilon i v$ ). In that case why does he use that word? Both words imply getting back something that was once ours but slipped away. 
So the whole process starts with the conscious possession of the knowledge, goes through its temporary loss and then returns to exactly the same state as before.

There is an implicit assumption here about what it is for knowledge to be 'in' someone: if knowledge is in someone, then he must either be aware of that knowledge or have been aware of it. I shall call this assumption (A). Without it, the immediate move to recollection would not make any sense. For the moment let us shelve the question of the historical Plato's position vis- $\dot{a}$-vis this assumption (i.e. whether Plato thought the assumption through but omitted to make it explicit in his writing, or whether he simply moved on to recollection without thinking); for the moment all I want to point out is that the assumption is necessary for the argument and that without it Platonic innatism would begin to slide towards a theory of implicit knowledge. Other innatists might agree that the slave boy must have the knowledge 'in' him, and that learning is the extraction of this knowledge, but they would argue that this in itself does not imply that the learner has been previously aware of the knowledge that is within him. Rather than import the extra premises about the knowledge within, others might be content to entertain some notion of implicit knowledge, that can exist without us being aware of it.

Now (A) may be a crucial premise for Plato but by a strange irony it was also a coping stone of one of the most famous critiques of innatism, the opening book of Locke's Essay concerning human understanding.

Locke's statement of (A) comes very near the beginning of his attack on innate ideas. At Essay $1.2 \$ 3$, he begins his attack on innate ideas by focusing on the claim made by many of his contemporaries that there are some truths that are innate because they command universal assent. This he rejects as a non sequitur because their commanding universal assent is not proof of innateness. But he goes on to claim that there is no universal assent anyway as children and idiots are quite ignorant of these truths $(\$ 5)$. It is difficult at first to see why anyone should think that everyone, including infants, is aware of these truths, and Locke has been accused of attacking a straw man. ${ }^{8}$ But Locke's strategy becomes clearer if we go on to his explanation of what he understands by the expression 'truths imprinted upon the soul':

It seeming to me a near Contradiction to say that there are Truths imprinted upon the Soul which it perceives or understands not; imprinting, if it signify anything, being nothing else but the making certain Truths to be perceived. For to imprint anything on the Mind without the Mind's perceiving it seems to me hardly intelligible... No Proposition can be said to be in the Mind which it never yet knew; which it was never conscious of. For if any one may; then, by the same Reason, all Propositions that are true, and the Mind is capable ever of assenting to, may be said to be in the Mind and to be imprinted: Since if any one can be said to be in the Mind, which it never yet knew, it must be only 
because it is capable of knowing it; and so the Mind is of all Truths it shall ever know.... So that if the Capacity of knowing be the natural Impression contended for, all the Truths a Man ever comes to know, will, by this Account, be, every one of them, innate; and this great Point will amount to no more, but only to a very improper way of speaking;...9

The principle upon which his argument is based could be put as follows: For $a$ proposition to be in a mind at time $t$, that mind must be conscious of that proposition at time $t$, or must have been conscious of it at some time prior to $t$.

This, of course, is identical to (A) and Locke uses it to impale the innatist on a massive trilemma. In the paragraph immediately proceeding the quotation Locke has dismissed (on empirical grounds) the idea that infants and idiots can be aware of their alleged innate notions; the next move is for the innatist to claim that everyone is in possession of the innate notions without necessarily being aware of them. Locke then invokes (A) to argue that this is necessarily false: if you have a notion, then necessarily you must be aware of it (or must have been aware of it). The third stage comes when Locke generously offers the innatist an escape-route: rather than say what is necessarily false he can admit that talk of a notion imprinted on the mind without its awareness amounts to no more than the claim that the mind can come to know that truth. But, as he goes on to argue, if this is what the innatist means, then all the propositions that we come to know, and many more besides, will be called innate.

In effect, what Locke has done is, starting out from (A), to offer the innatist a trilemma:

either (i) the innate principles are known to everyone of any age

or (ii) they are known implicitly without the mind's awareness

or (iii) they are truths which the mind is capable of coming to know.

(i) is obviously absurd and trivially false, but of the alternatives, (ii) contravenes (A) and so is necessarily false and (iii) appears to render the innatist thesis trivially true. ${ }^{10}$

The challenge to the innatist is somehow to wriggle out of Locke's trilemma. It is important for him to decide whether or not he wants to accept (A). If he denies it Locke's second limb is no longer a worry for him and so he escapes the trilemma unscathed. If he agrees with (A) (ii) will remain a stumbling block and in order to escape the trilemma he would need to show either that it is not exhaustive and that other alternatives more conducive to an innatist are possible, or that of the two lemmas, (i) and (iii), one is not as silly or as unpalatable as Locke would have us think. This means remodelling (i) or (iii).

One person who opts for a denial of (A) and hence a straight rebuttal of (ii) is Leibniz. In direct response ${ }^{11}$ to Locke's claim that there cannot be truths 
imprinted upon the soul which it does not perceive he replies that we know an infinity of things which we are not aware of all the time, and we use memory to make them explicit to us: we know that $2+2=4$ without being conscious of it all the time and we could not possibly think of everything we know all at once. Of course, this is an inoffensive point with which Locke could hardly take issue. But Leibniz is soon found extending the principle to cover truths imprinted on the soul of which it has never been aware. As we have seen, to Locke this means no more than that the mind is capable of knowing such truths. But Leibniz is ready with a reply:

Since an item of acquired knowledge can be hidden there [sc. in the mind] by memory, as you admit it can, why could not nature also hide there an item of unacquired knowledge? Must a self-knowing substance have, straight away, actual knowledge of everything that belongs to its nature? Cannot - and should not - a substance like our soul have various properties and states which could not all be thought about straight away or all at once? ${ }^{12}$

Leibniz is thus committed to a theory of latent or implicit knowledge, so that learning of certain truths is really a process of making something already there in the soul explicit. As Leibniz is well aware, his position is rather like the theory of recollection only purged of pre-existent souls. ${ }^{13}$

Other ways of evading Locke's trilemma would be to accept (A) and remodel (i) or (iii). Let me begin with (i). Remember that one innatist who agrees with Locke in accepting (A) is Plato. For him, children and idiots are in possession of their innate knowledge in the sense that they have actually been aware of the knowledge on a previous occasion. It is precisely because of their pre-existent lives that Plato can fulfil Locke's conditions for having knowledge within one without having to say that everyone is aware of his knowledge at birth. In effect, he takes advantage of Locke's temporal qualification in (A): we must be aware of any idea we have or at least have been aware of it previously.

This puts Plato, Locke and Leibniz in a rather curious relationship. On one point Plato is in obvious agreement with Leibniz: both philosophers thought that, for certain truths, we cannot get knowledge from the empirical input - so there must be a large a priori element. But, as must now be clear, Plato also has a foot in Locke's camp in that his agreement with (A) is implicit in and necessary to his argument for recollection. In fact you only have to combine Leibniz' point with Locke's criticism and one result is Plato's theory of recollection. Or, to put it another way, Platonic innatism, unlike the Leibnizian variety of innateness, can co-exist quite happily with everything that Locke says in $1.2 \$ 5$ precisely because both Plato and Locke use (A) as a crucial premise.

The other way of coping with Locke's criticism without denying (A) is to challenge his third lemma in which innatism is reduced to the uncontroversial 
point that we are capable of coming to form a number of ideas or know certain truths. There is, however, a difference between bare capacities to form any ideas and pre-dispositions or potentialities to form certain beliefs rather than others. Hence we should make a distinction between the banal claim that the mind is able to form the ideas that it does form, and the claim that the mind is innately disposed to form a certain set of ideas whatever its experience. This second claim amounts to a theory of 'dispositional' innateness to which Descartes and some of the Cambridge Platonists had already subscribed. ${ }^{14}$ To illustrate this type of innateness, Descartes talked of ideas being innate to us as certain diseases are innate to some families. ${ }^{15}$ In using the analogy he emphasized that the infants of such families do not possess the disease in their mothers' wombs but merely have a certain propensity to contract them. Similarly, babies are not born actually in possession of their innate ideas but only with the disposition to form them. Thus Descartes is happy to say that innate ideas and the mind's capacity to think come to the same thing.

What is being ruled out here is a bare capacity such that what is learnt is simply a question of whatever we happen to experience. According to dispositional innatism, we may ostensibly start out with a tabula rasa (just as Descartes' child is truly healthy), and we do rely on our perceptions to learn, but we are so built as to favour the formation of a certain group of ideas or beliefs as opposed to others. The essential idea is that the mind is so structured as to form certain ideas and beliefs about whatever it may happen to encounter in experience; there is therefore a limiting factor that derives from the nature of the mind itself and is not dependent upon experience.

On this view it is not the ideas themselves that are innate but the dispositions to form them. Thus the disagreement between Locke and the dispositionalist is not over (A) but over the claim that the mind is predisposed to form certain specific ideas and beliefs. The rejection of such a claim is implicit in Locke's argument of $1.2 \S 5$ and recurs throughout his polemic against innatism. He was particularly adamant about practical principles on this point: there is no privileged set of moral principles which we are disposed by nature to form. Thus, in response to those who claimed that certain moral principles were innate because of the alleged fact of a consensus omnium he appealed to several reported cases of foreign tribes flouting these same principles: the Mengrelians, who professed to be Christians and yet buried their children alive, and the Tououpinambos, who considered revenge and 'eating abundance of their enemies' to be the very pinacle of virtue. ${ }^{16}$

In reply the dispositionalist can simply argue that Locke is wrong to rush straight into talking about bare faculties and to ignore the possibility of specific potentialities. ${ }^{17}$ His trilemma fails to trap the innatist because (iii) is too crude.

So just as Platonic recollection can be seen as a twist on (i), dispositional innatism can be seen as a twist on (iii), both of them agreeing with Locke on (A). 
We have yet to ask whether either of these variations succeeds where their originals failed but, before doing this, let us, for the sake of clarity, take stock of some of the different positions that we have distinguished so far in the debate between innate ideas and empiricism. At one extreme is Lockean empiricism, rejecting all innate ideas and all dispositions to form any set of beliefs in particular. At the innatist extreme we can put two theories, one being crude innatism, apparently espoused by some of Locke's contemporaries, which claims that we have been conscious of our innate knowledge from birth. ${ }^{18}$ As this means ascribing to idiots and infants conscious awareness of their innate knowledge, we could instead appeal to Platonic anamnesis without denying the claim that we have been aware of the knowledge that is within us. But a much less extreme innatist position is dispositional innatism which admits that the knowledge itself is not innate, whilst holding that we are not a tabula rasa but endowed with innate propensities to form certain beliefs rather than others. All these positions can accept (A) but react in obviously different ways to it. We should now add to our list Leibniz' implicit or unconscious knowledge which is a form of innatism that does not agree with (A).

Let me now return to the variations on (i) and (iii), recollection and dispositionalism, and ask how successful they have been in evading Locke's criticism. Remember that originally (i) was trivially false and (iii) trivially true. The problem that immediately strikes us about recollection is that although it is not so easily refuted as the claim that infants and idiots are aware of their innate principles, it is none the less incredible. This brings us back to the charge that I levelled against Plato at the beginning of this section: if there are other forms of innatism that are neither trivial nor incoherent do they not constitute philosophically better answers to Plato's problem than his own metaphysical extravaganza? It is important to answer this question because doing so will enable us to see whether or not there is some sound philosophical reasoning at the heart of the differences between the first theory of innateness and its successors.

If Plato is to be expected to avoid the metaphysical expense of recollection he must be offered alternatives. Now so far we have distinguished two varieties of innatism which are obviously proposing alternatives to recollection. There is the innatist who simply rejects the truth of (A), as Leibniz does in some of his moods, and who talks of implicit knowledge, or the dispositionalist who allows for the truth of (A) and talks of innate propensities to know rather than innate knowledge. Why could Plato not have made do with one of these?

To answer this question, we need to bear in mind why Plato proposed the theory of recollection in the first place. He did so as part of an argument for the possibility of attaining the kind of knowledge that Socrates disclaims for himself and which he shows is lacking in his interlocutors: that is the kind of knowledge that could withstand the gruelling examinations that feature in all the Socratic dialogues. In the Meno, particularly, this knowledge is manifested by the ability 
to give an account of some subject that involves an articulated explanation. ${ }^{19}$ Thus it should come as no surprise that one of the themes of the Meno is that knowledge can only be attained by the learner's working through a problem for himself; the last thing he should be doing is reciting what his teachers have told him. ${ }^{20}$ This is stressed throughout the interview with the slave boy, particularly in the passage that I quoted above: ${ }^{21}$ here Socrates says twice that the slave boy will not only derive knowledge from himself but will do it for himself, the word aviòs being repeated at $85 \mathrm{~d} 4$ and at $\mathrm{d} 6$. It is also the point of the analogy of knowing the road to Larissa that is used later on in the dialogue: you do not know by consulting a guide but by seeing it for yourself (97a9-b7).

It should be obvious by now that both Leibniz' implicit knowledge and dispositional innateness would fail to satisfy the epistemological conditions that Plato has set himself. If understanding a subject involves something as deliberate as working it through for yourself, Plato could hardly accept the idea of our having knowledge of which we have never been aware. Now, this does leave open the possibility of our having innate true beliefs of which we have never been aware, but Plato was only interested in true belief in so far as it lies en route to philosophical understanding.

To all intents and purposes, therefore, Plato's insistence that to know something you must have worked it out for yourself means that he has to accept the truth of (A), and so he must reject any alliance (on this issue) with a philosopher like Leibniz who denies that assumption.

And if Plato could not have made much use of implicit innatism he would have made even less of dispositionalism. What the dispositionalist has given up in resisting the notion of a bare faculty, impartial to all and any truths, and so escaping Locke's charge of triviality, is the claim that any knowledge is within us: what is innate to us are merely dispositions to know or form beliefs. Dispositionalism may indeed be a less extravagant thesis than the theory of recollection, and one that involves no denial of (A), but it sacrifices precisely the claim that is so important for Plato, namely that the knowledge is in us and has been thought through by us.

So there are, after all, good reasons for Plato's not taking up either dispositional innatism or implicit knowledge. Now that we have settled this point we can turn back to dispositional innatism to ask whether, in answering the charge of being trivially true that Locke made against (iii), it can really lay all innatist fears to rest. The dispositionalist does seem to have avoided the threat of triviality that Locke's dilemma posed in $1.2 \$ 5$ because Locke gives no argument for his rejection of predispositions to form select beliefs. But although the dispositionalist has escaped from the embarrassing predicament of having to agree with Locke, this is not all he has to do. Empiricism comes in many different forms other than the Lockean variety and so to show that the dispositionalist is in 
disagreement with Locke is not to show that he is actually saying anything with which a less extreme empiricist would take issue. This is the problem I referred to in the introduction which has exercised the commentators on the innatist/ empiricist debate. To make the problem most acute, let me turn briefly to a point that has been made in the modern debate over innatism.

Recently, Quine has pointed out that the modern empiricist in the form of the behaviourist actually needs a sizeable quota of innate dispositions. Behaviourism depends upon the reinforcement or extinction of responses to given stimuli. Imagine that a subject responds to a given stimulus in a certain way and is rewarded; he then responds in the same way to a second and different stimulus and is punished. If in the presence of a third stimulus he responds in the same way again, this reflects the fact that the subject treats the third stimulus as more similar to the first than to the second, that is the third stimulus is closer to the first on the subject's scale of similarity than it is to the second. Quine has referred to this as an inequality in the subject's spacing of qualities, or quality space. This is how he makes the point in Natural kinds:

A standard of similarity is in some sense innate. This point is not against empiricism; it is a commonplace of behavioural psychology. A response to a red circle, if it is rewarded, will be elicited again by a pink ellipse more easily than by a blue triangle; the red circle resembles the pink ellipse more than the blue triangle. Without such prior spacing of qualities, we could never acquire a habit; all stimuli would be equally alike and equally different. ... Needed as they are for all learning, these distinctive spacings cannot themselves all be learned; some must be innate. ${ }^{22}$

Quine, following Skinner, wanted to use behaviourism to explain language learning and so claimed that if a child is to learn to use the word 'Red' by saying it in the presence of a red object and being rewarded on such occasions we must credit the child with a sort of pre-linguistic quality space, 'otherwise a dozen reinforcements of his response 'Red', on occasions where red objects were presented, would no more encourage the same response to a thirteenth red thing than to a blue one. ${ }^{23}$

In another article, 'Linguistics and philosophy', Quine used these considerations to argue that Chomsky is not proposing anything that at least this type of empiricist need disagree with: ${ }^{24}$ 'the behaviourist is knowingly and cheerfully up to his neck in innate mechanisms of learning readiness'.

But this syncretism need not be confined to discussions of behaviourism; does every empiricist have to go all the way with Locke in rejecting anything but bare faculties? It is hardly controversial to admit that since all men naturally feel pain they will have a notion of pain. Thus they are predisposed to form this particular 
idea. Indeed, did Locke himself really believe that there are no internal limiting factors whatsoever? He does in fact have a small concession to make in Essay 1.3 $\S 3$ :

Nature, I confess, has put into Man a desire of Happiness, and an aversion to Misery: These are indeed innate practical Principles, which (as practical Principles ought) do continue constantly to operate and influence all our Actions, without ceasing: These may be observ'd in all Persons and all Ages, steady and universal; but these are Inclinations of the Appetite to good, not Impressions of truth on the Understanding. I deny not, that there are natural tendencies printed on the Minds of Men; and that from the very first instances of Sense and Perception, there are some things, that are grateful and others unwelcome to them; ... But this makes nothing for innate Characters on the Mind, which are to be Principles of Knowledge... .

Although there may be inborn tugs of appetite that does not mean any inborn intellectual tugs towards certain notions or beliefs. But in reply Leibniz argues that Locke has now sided with the innatists:

PHILALETHES [speaking for Locke]. Nature has put into man a desire for happiness and an aversion to misery; these are indeed innate practical principles which (as principles ought) continue constantly to influence all our actions; but these are inclinations of the soul to good, not impressions of some truth that are engraved on the understanding.

THEOPHILUS. I am delighted, Sir, to find that you do after all acknowledge innate truths as I will shortly maintain. The principle agrees well enough with the one I have just pointed out which leads us to pursue joy and avoid sorrow. For happiness is nothing but lasting joy. However, what we incline to is not strictly speaking happiness but rather joy, i.e. something in the present; it is reason that leads to the future and to what lasts. Now an inclination that is expressed in the understanding becomes a precept or practical truth; and if the inclination is innate then so also is the truth - there being nothing in the soul that is not expressed in the understanding... .

(New essays $1.2 \S 3$ )

Leibniz seems prepared to say that when an innate tug of appetite gets expressed as an idea that idea should be called innate. The point is that because of this tug of appetite we are bound to form certain ideas whatever the circumstances in which we live. ${ }^{25}$ Now imagine if Locke had conceded the truth of this to Leibniz: his next move might be to say that innatism so construed is a rather trivial thesis. 
All men of their own nature feel pleasure and pain, so you can be asured that wherever they live and whatever happens to them they will have the notions of pleasure and pain. No one would deny that the dice were loaded from the start, but if that is all innatism amounts to it is difficult not to share Locke's sense of anticlimax. What would make an innatist case interesting would be if, for instance, the belief in the existence of God were innate just as that of pleasure is. So perhaps the real debate is not about whether there is any innate endowment at all - that is a rather uncontroversial point - but about the size and richness of this endowment.

Motivated by considerations such as these, some scholars have wondered what was really at issue in the Locke/Leibniz debate and go on to point out that innatism or its rival acts as a sort of figurehead for much more serious philosophical battles. ${ }^{26}$ What Locke is attacking much of the time, and what Leibniz defends, is not merely the claim that we are innately disposed to form some beliefs rather than others, but that these ideas or beliefs are epistemologically basic, acting as the foundation of, for instance, moral, theological, mathematical, or logical knowledge. Leibniz was painfully aware of the fact that mere sense experience could not possibly justify knowledge of necessary truths (as opposed to the particular instances of which experience informs us) and so appealed to an inner source of justification. ${ }^{27}$ But Leibniz was not alone in looking beyond the confines of human psychology when he defended innatism. Both Descartes and the Cambridge Platonist Henry More had started out from the idea men have of God, which happens to be innate, in order to prove his existence. ${ }^{28}$ It was therefore crucial to them that this innate idea was trustworthy. In the realm of practical principles too, the situation was the same: many of the philosophers and clerics whom Locke had attacked had not been interested merely in pointing out the alleged innateness of moral principles but, ultimately, in justifying their acceptance..$^{29}$

The point of saying that the innatist debate is really a figurehead for something else is that many of the uses to which philosophers have put the above arguments about innate knowledge seem only to be tenuously connected with innatism: that we have ideas or dispositions to form ideas or beliefs that derive from some feature of our minds that is prior to sense-perception may be an interesting thesis for the cognitivie psychologist, but is not on its own sufficient to justify belief in the truth of those ideas. Such a psychological thesis has little epistemological power. Even in Locke's time someone had argued that the mere fact of our having an innate belief hardly justifies its acceptance: our head could be stuffed with any old rubbish. ${ }^{30}$

How did the proponents of innatism meet such a challenge? Some appealed to the naturalness of innate ideas: certain principles command universal assent and are prior to experience; hence their ubiquity is not a product of some feature in 
the world but must proceed from human nature itself, i.e. they are woven into our very fabric as essential and necessary to it. Certain philosophers thought it enough to stop the argument there because for them anything so intrinsic and necessary to human nature should command unquestioning respect. ${ }^{31}$ In its reverence for human nature this argument already makes an implicit appeal to providence and so it is not surprising that it sometimes derived explicit support from theology: as these innate principles are part of human nature they must have been put there by the artificer of human nature, God, who is provident and therefore veracious. Ultimately, therefore, it is theology that gives innatism its epistemological clout. ${ }^{32}$

But whatever reasons philosophers gave for their trust in innate principles, the point I wish to stress is that even before we have made distinctions between implicit and dispositional innatism, there is a fundamental choice to be made: are we to use one or other brand of innatism merely to tell us something about the origin of certain beliefs or about their justification? A psychological interest in innatism confines itself to the claim that by the nature of our own minds we are inclined to form certain specific beliefs (if the preferred brand is dispositionalism). As we have seen, the issue here is really about how much is innate, and the thesis is more or less interesting depending on the richness of the endowment. The other interest in innatism is epistemological and has often been associated with an unquestioning respect for human nature, if not an outright appeal to theology. ${ }^{33}$

\section{(2) A return to the Stoa: the conflicting evidence}

Now that we have a clearer idea of the hazards involved in talking about innate ideas or knowledge it is time to turn back to the historical debate about the Stoa and look at some of the evidence. ${ }^{34}$ As we have seen, the text that seems to torpedo the innatist case is this passage of Aëtius that I translated above: ${ }^{35}$

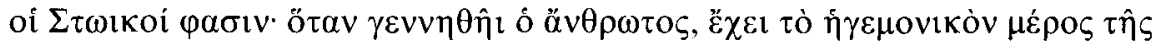

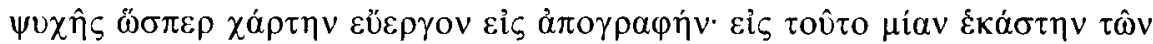

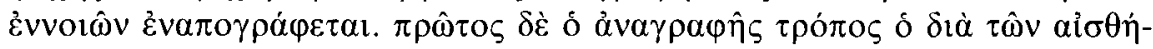

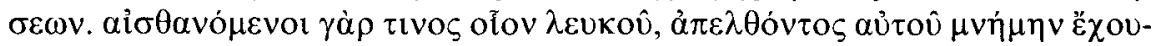

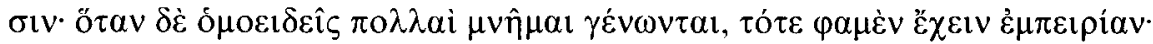

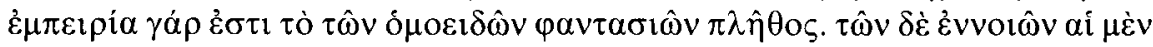

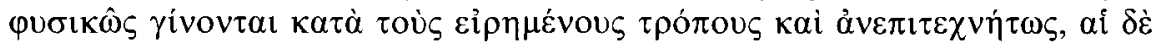

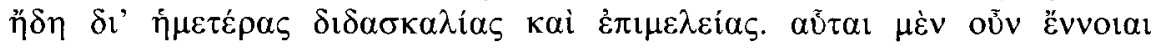

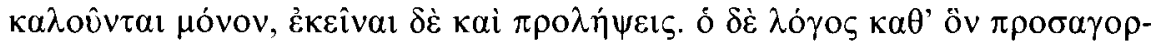

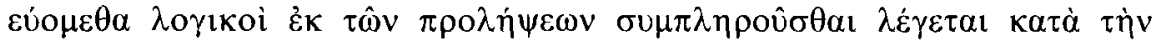

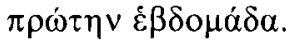


This seems to assert the existence of a tabula rasa and to have notions inscribed upon the mind in true empiricist fashion. It is not surprising therefore that those who have proposed the innatist interpretation of the Stoa have been accused of ignoring the evidence of this fragment.

Nevertheless, there is a reasonable amount of evidence that, at the very least, suggests that the account that Aëtius gives is not the whole story. To begin with, there are three passages that make a connection between nature and our moral concepts or their formation. Two of these come from Plutarch, one from Diogenes Laertius.

I have already quoted one of the Plutarch texts, Comm. not. $1070 \mathrm{c}-\mathrm{d}$. Here it is again, this time a little more in context:

Has there ever been an another argument that does greater outrage to common experience....and this too in matters concerning good things and evil and objects of choice and avoidance and things congenial and repugnant, the clarity of which ought to be more manifest than that of things hot and cold and white and black, since the mental images of these are incidental to the sense-perceptions entering from without whereas the former are generated intrinsically from principles within us?

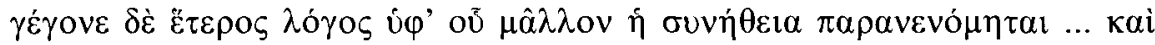

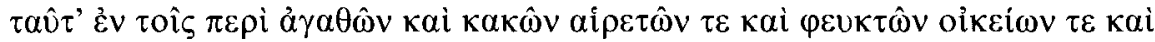

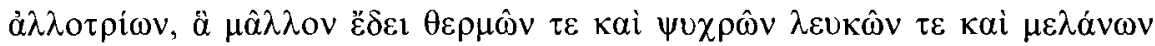

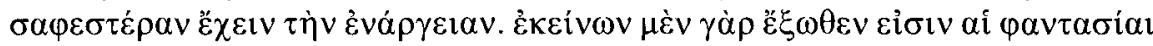

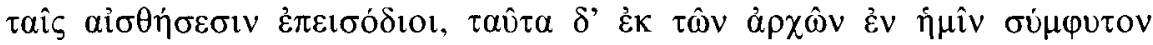

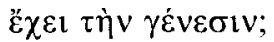

(Comm. not. 1070c-d $)^{36}$

A contrast is being set up between the origin of our ideas of sensible things, such as hot and cold or black and white, and our moral notions. The former category are adventitious, the latter owe their origin to an internal source. The word I am

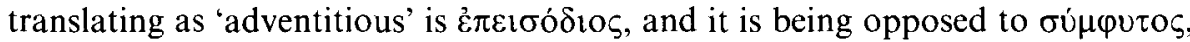
an opposition that is reinforced by $\ddot{\varepsilon} \xi \omega \theta \varepsilon v$ and $\dot{\varepsilon} v \dot{\eta} \mu \hat{\imath} v$.

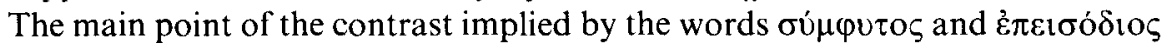
is between something that is internal, necessary and natural to a person or thing, and something incidental or unnecessary. This becomes clear if we take a quick look at other uses of $\dot{\varepsilon} \pi \varepsilon \iota \sigma o ́ \delta$ to $\zeta$ and $\sigma u ́ \mu \varphi v \tau o \zeta$ in Plutarch. In a passage that looks similar to ours, Plutarch talks of man having something of the irrational in him which is a connate source of emotion. As it is connate it is not incidental but necessary to us and hence we should educate and nurture it rather than try to remove it entirely (De Virtute Morali 451c). Elsewhere (De Gen. Soc. 584e), he 
makes a distinction between desires, some of which are innate ( $\ddot{\varepsilon} \mu \varphi v \tau o s)$ and correspond to necessary pleasures, others merely alien ( $\dot{\varepsilon} \pi \dot{\eta} \lambda v \delta \varepsilon \zeta$ ), incidental

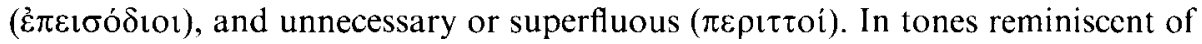
the previous passage we are told to uproot this latter kind of desire. Another passage where a similar contrast is made is Quaest. Naturales $914 \mathrm{~b}$ where Plutarch contrasts the intrinsic warmth of the sea ( the incidental $(\hat{\varepsilon} \pi \varepsilon 1 \sigma o ́ \delta 10 \varsigma)$ and alien $(\dot{\alpha} \lambda \lambda \dot{o} \tau \rho\llcorner o \zeta)$ warmth of other liquids, and claim that the former, unlike the latter, cannot be dislodged by movement.

If these words are working in similar ways in $1070 \mathrm{~b}-\mathrm{c}$ then the point of this passage is that concepts of black and white are not part of or necessary to our nature, and so their formation is contingent upon external factors, whereas moral concepts derive from features inherent in and necessary to human nature so that they will be formed whatever our experience, just as the sea will be warm whatever the winds are doing. ${ }^{37}$

The other passage in Plutarch that suggests that Aëtius is not telling the whole story is Stoic. Repug. 1041e-2a where Chrysippus is said to have called moral prolepses $\varepsilon \mu \varphi v \tau o 1$ and, not surprisingly, proponents of the innatist interpretation have seized upon this text, translating the words as 'innate' without further ado. There is no doubt that the use of the word fits well with $1070 \mathrm{c}-\mathrm{d}$. As in this passage, 1041 seems to limit the ascription of innateness to moral notions, and the use of the word $\ddot{\varepsilon} \mu \varphi v \tau o \zeta$ rather than $\sigma u ́ \mu \varphi v \tau o \zeta$ does little to spoil the closeness between these two texts: notice that in two of the passages I quoted, 451 and 584, very similar contrasts were made both using the word $\dot{\varepsilon} \pi \varepsilon 1 \sigma$ ó $\delta$ เot for what is alien and unnecessary, but one passage used $\sigma u ́ \mu \varphi v \tau o \varsigma$ for what is intrinsically natural, the other $\ddot{\varepsilon} \mu \varphi v \tau o \zeta$. This suggests that there is not a very significant difference in meaning between the words. It is not surprising therefore that $1041 \mathrm{e}-2 \mathrm{a}$ has given comfort to scholars who wanted to ascribe an innatist theory to the early Stoa and a certain amount of trouble to the empiricist interpretation: translations other than 'innate' have been proposed, but have proved difficult to sustain on closer examination. ${ }^{38}$

Another text that has been used for the innatist case is D.L. 7.53:

It is by confrontation that we form notions of sense-objects. By similarity of things based on thoughts of something related, like Socrates on the basis of a picture. By analogy sometimes by magnification, as in the case of Tityus and the Cyclopes, sometimes by diminution, as in the case of the Pigmy; also the idea of the centre of the earth arose by analogy on the basis of smaller spheres. By transposition, things like eyes on the chest. By combination, Hippocentaur. By opposition, death. Some things are conceived by transition, such as sayables and place. The idea of something just and good is acquired naturally. That of being without hands, for instance, by privation. 


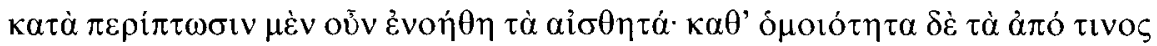

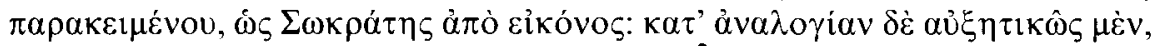

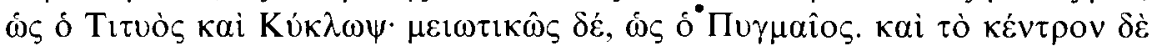

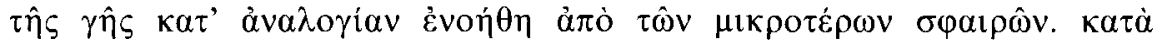

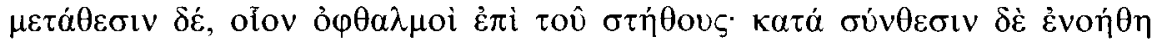

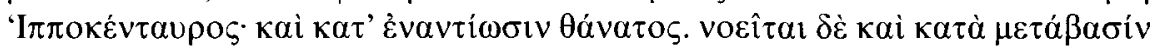

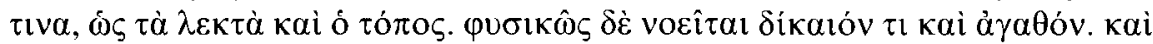

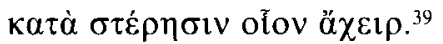

The claim has been made that the adverb 'naturally' ( $\varphi v \sigma ı \hat{\omega} \varsigma$ ) which applies to the formation of the moral concepts listed indicates innateness. ${ }^{40}$ But at first sight it is difficult to see why one should read so much into this one word. After all, in the Aëtus passage the same word merely means that some notions come without any instruction or intellectual effort, so why should we not adopt this simpler and apparently more economical reading in the Diogenes passage? Indeed, this is surely the sense of the adjective $\varphi v \sigma ı k \eta$ that is used in Diogenes' next paragraph

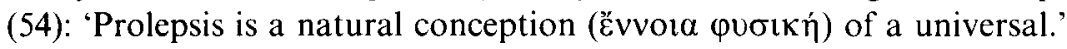

However, things are not quite so easy as this. What tells against this economical interpretation of the adverb 'naturally' in 53 is that already in this paragraph most 'natural' prolepses (e.g. of directly sensible qualities) have already been dealt with under the category of $\pi \varepsilon \rho i \pi \tau \omega \sigma \imath \zeta$, while the moral notions whose formation is said to happen 'naturally' are presumably meant to form a subsection of our prolepses; so whatever 'naturally' means, it does not apply to prolepses of sensible things, and so must mean more than that these prolepses are formed without learning.

What makes this passage in Diogenes so tempting for the innatist interpretation is the embarrassment it causes the opposition. We need to find out what it is about the formation of moral prolepses that merits their being put in a class on their own, ${ }^{41}$ but unless we can find a gloss on 'naturally' that fits in with the empiricist interpretation, we are left with an awkward blank in this important passage which the innatist interpretation is only too happy to fill.

The general theme that runs through these three passages is that for the Stoics there is a basic division between notions that come purely as a result of perception or 'confrontation' - and whose formation is determined by what we happen to experience - and those that proceed from our intrinsic nature, so that, presumably, you will find people forming these notions whatever their experience. On the strength of these few passages, therefore, one can see that if the Stoics were innatist, their innatism was limited to moral notions.

Before I leave this group of passages, let me just point to some evidence that could be used to show that if there was innatism in the early Stoa it persisted in the later Stoics, Seneca and Epictetus. 
In Ep. Mor. 120, Seneca tackles the question of how the notion of good first came to us and answers that it comes by analogy. But he also has something to say about the beginnings of the process:

Nature could not teach us this [sc. the good]; she has given us the seeds of knowledge, but not the knowledge itself.

Hoc [bonum] natura nos docere non potuit; semina nobis scientiae dedit, scientiam non dedit.

What he goes on to do is to say how we did learn the scientia if Nature did not teach us - and this is by analogy.

The phrase Natura semina nobis dedit can be used to explain the word 'naturally' in D.L. 7.53. For one thing it makes sense of the $\tau$ that qualifies

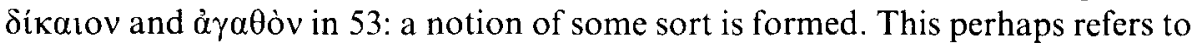
an inarticulate notion requiring scientific explication - exactly the same point as made by Seneca: Nature gives us the beginnings of the idea, we finish it off. One could take this further and say that what Nature gives us is given prior to any sensation and is innate, thus tying this passage together with the innatist story that we have pieced together from Plutarch 1041 and 1070, and D.L. 53.

But although this is a possible interpretation it is not the only one, and on their own Seneca's words do not rule out the alternative possibility that Nature sows its seeds by sensation rather than prior to it.

The same cannot, however, be said of the later Stoic, Epictetus, whose innatism is clearly set out in this passage:

We do not come into being with a natural concept of a right-angled triangle, or a half-tone musical interval, but are taught each of these by some technical or systematic instruction, and so those who do not know them do not even think that they know them. Who, on the other hand, has not come into being with an inborn concept of good and evil, fine and base, appropriate and inappropriate, of happiness, of what is proper and what is one's fate, and of what one ought and ought not to do?

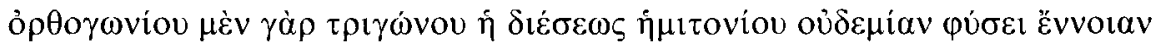

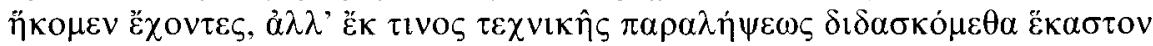

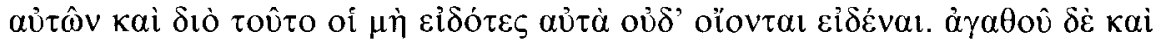

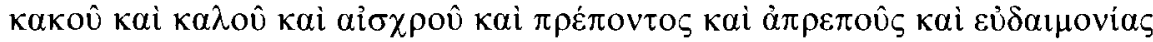

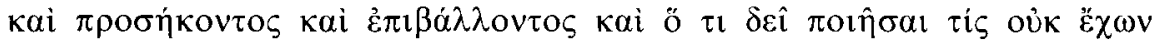

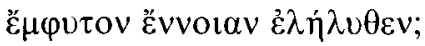

(Diss. 2.11.2 3) 


\section{(3) The appeal to oikeíwoıs}

On the view we are developing, the early Stoics thought that in the formation of moral notions we are given a helping hand by features intrinsic to our nature and so Epictetus' innatism does not amount to radical heterodoxy, but is merely a robust affirmation of the official line on the subject. But, whatever one thinks about Epictetus, how is this view of the early Stoa to be reconciled with Aëtius' testimony? Some scholars have sought to do this by appealing to another body of evidence connected with the doctrine of oikeiwors. The major proponent of this interpretation has been Pohlenz. ${ }^{42}$ On his interpretation, what makes moral prolepses special is that they derive from man's inborn tendency to evaluation, and this he connects to the doctrine of oikei $\omega \sigma \mathrm{ic}$ according to which all animals are innately well-disposed to the beneficial and reject the harmful. Pohlenz's point is that from the moment of birth we do not treat the things we perceive merely as objects of outside experience, but as related to ourselves, being either useful or beneficial. As we mature, this instinct becomes expressed by $\lambda$ ó $\gamma \circ \zeta$, and so our moral concepts are formed. These concepts are the result partly of inner experience - consciousness of the self - which is an integral part of oikeíwoıs. For Pohlenz this explains why moral notions are grouped separately in D.L. 7.53; it also provides a good gloss on Chrysippus' description of them as ह̌ $\mu \varphi v \tau o$, and Seneca's semina - and all this without contradicting the Aëtius fragment.

This interpretation also makes heavy use of Plutarch Comm. not. 1070c-d. Pohlenz, followed by Cherniss and Luschnat, ${ }^{43}$ refers to Hierocles' treatment of

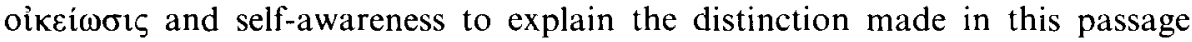
between concepts with an external origin and those with an internal one. At col. $6,1-19$, Hierocles points out that we do not merely experience hot and sweet things (Plutarch's first category) but are also heated and sweetened - for outer experiences there are corresponding inner ones. Pohlenz seems to steer between Sandbach and those who endow the Stoa with innate moral prolepses - a position that would not be consonant with Aëtius' picture of the mind as a tabula rasa at birth.

Now there are a number of things that make me feel uneasy about all this. First, I think Pohlenz and others, as a result of their interest in oikei $\omega \sigma \iota \varsigma$, make too much of self-awareness in all this. In fact, self-awareness is not strictly relevant to Plutarch $1070 \mathrm{c} d$. There the distinction is between one group of concepts that come as a result of the bombardments of sense-perception, e.g. white, black, hot and cold, and another that derives from our own nature, e.g. good and bad. Hierocles' distinction is indeed between the internal and the external. But the internal includes internalized feelings corresponding to the externals, e.g. feeling of heat, and that has nothing to do with moral concepts. Perhaps we might bring self-awareness into the formation of moral concepts, but 
that will not be the essence of what distinguishes the formation of moral notions and so at best only a part of what Plutarch is talking about.

Second, Pohlenz's interpretation attempts to rsolve one controversy by

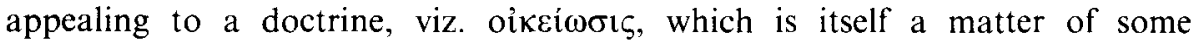
controversy. One of the problems is that it is not clear whether oikeíwois on its own can provide sufficient starting-points for moral notions. I take it that Chrysippus believed in the theory of oikcíols to the extent that all animals pursue and avoid what is beneficial and harmful, respectively. But this is common to all animals, and moral notions are not. Is there a specifically human form of

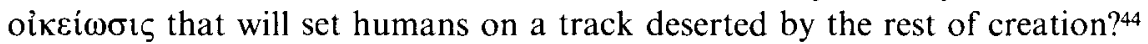

Despite these problems, however, I think that Pohlenz is probably right in the general thrust of his verdict that the clue to understanding why moral notions are $\varepsilon \mu \varphi v \tau o t$ lies in our innate disposition towards evaluation, a point that Irwin has

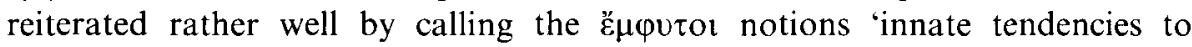
interpret perceptions and experiences in particular ways' ${ }^{45}$ But I think that it can

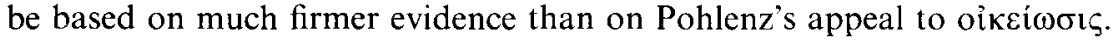

\section{(4) The argument from à $\varphi \rho \rho \mu \alpha i$}

If one is interested in the connection between oiksi $\omega \sigma \mathfrak{l} \varsigma$ and the development of our moral sense one place to look is Galen's De Placitis Hippocratis et Platonis 5.5. In this passage Galen compares Platonic and Stoic views on the origin of vice. Plato, he says, recognized with his three-fold division of the soul that there are three things with which we feel a natural kinship, pleasure, victory and moral excellence, whereas Epicurus and Chrysippus both erred in thinking that man only has a natural kinship with one of these three; for Epicurus it was pleasure, for Chrysippus moral excellence. Galen goes on to criticize Chrysippus severely for this and for being unable to account for the fact that children do not automatically do what is morally right - even if they received an impeccable upbringing from philosophers, they would not necessarily become philosophers themselves. Chrysippus did try to explain this by saying that although we do have a natural kinship with virtue, we can be led astray either by the influence of our associates or by the attractiveness of things around us. ${ }^{46}$

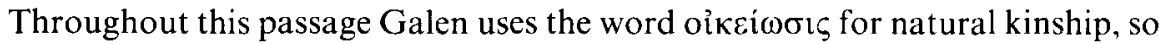
that at first sight, it is tempting to connect this text with other passages that use that word. But this would be a mistake. Galen also uses the word to apply to Plato and Epicurus, so it is thoroughly unlikely that he is referring to an exclusively Stoic doctrine. In this context, his use of the word oikciwois implies no more than that one has a natural leaning towards something.

This is not the only place where we find this contrast between our natural propensities and the origin of vice ascribed to the Stoa. Diogenes reports that when a rational being is perverted it is either because of the seductiveness of 
external pursuits or because of the influence of his associates: nature gives us unperverted starting-points (7.89). In this passage, the word that I am translating

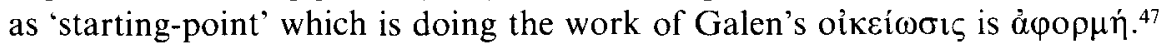

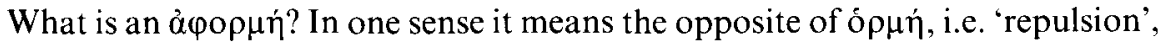
but this was a sense coined by the Stoics and 'starting-point' is the more usual meaning. The word can often be translated as 'resources', or sometimes as '[banker's] capital', and implies something which gets a process going or enables one to launch some operation, military or commercial, for instance. ${ }^{48}$ It is obviously the sense of 'starting-point' rather than 'repulsion' that is at work in D.L. 7.89, and the idea that nature gives us some starting capital, as it were, calls to mind Seneca's phrase, 'natura ... semina nobis scientiae dedit'.

The word $\alpha \varphi \circ \rho \mu \eta$ is used elsewhere in Diogenes' account of Stoic philosophy, in a logical rather than ethical context:

A reasonable proposition is one which has more resources to turn out true than not, such as "I shall be alive tomorrow."

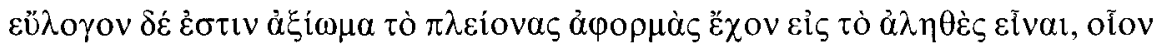

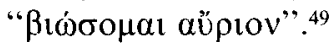

I take the point of this sentence to be that my present state of health is such that I am more likely to be alive tomorrow than dead. My present state of health is, as it were, the proposition's resources, or assets which make it inclined to come out true. This implies the notion of a disposition to come out in a certain way, and this fits the context of D.L. 7.89 very well indeed: if we have $\dot{\alpha} \varphi \rho \rho \mu \alpha i$ towards virtue given by nature, then, so long as there is no interference from our particular environment or associates, we shall behave in accordance with virtue. The course of our behaviour is already disposed towards virtue, just as the proposition was already disposed to come out true, but in either case, the other alternative could still come up trumps. Notice how the image of an innate disease would be quite at home in all this: in the natural course of events, that towards which we have a disposition will manifest itself. The essential point is that behaviourally we are disposed towards one thing rather than another, so that the idea of innate selection is well to the fore.

D.L. 7.89 is not the only place where the Stoics are said to have talked of inclinations to virtue. There are two passages in Stobaeus' Eclogae which seem to be making a very similar point. At $E c l .2 .65 .7$ (= SVF 1.566), Stobaeus ascribes to Cleanthes the view that men have $\alpha \varphi \circ \rho \mu \alpha i$ towards virtue given by nature; if a man's natural resources are left unfulfilled he is bad, if they are perfected he is good. Hence there is nothing between good and evil. ${ }^{50}$

Earlier on, however, at Ecl. 2.60 .9 ( = SVF III.264 p.65, 1-3), Stobaeus has given us a more detailed account of our natural inclinations towards virtue. For the 
Stoics virtue could be subdivided into four parts, wisdom, prudence, courage and justice. Each of these virtues is concerned with its own particular province, wisdom with the appropriate things, prudence with one's impulses, courage with endurance, and justice with distribution. We are then told (SVF III. p. 65, 11. 1-4) that all men have natural inclinations to the discovery of what is appropriate, to the steadying of their impulses, to endurance and to distribution. ${ }^{51}$ This passage re-affirms what we already know from D.L. 7.89, that we have inclinations to virtue, but shows how this rather general claim will work out once we have a more detailed account of what virtue is.

Looking at these passages as a group we can start to throw some light upon D.L. 7.53 and Plutarch, $1041 \mathrm{e}-2 \mathrm{a}$ and $1070 \mathrm{c}-\mathrm{d}$, which said that our moral notions are है $\mu \varphi \cup \tau o เ$ or arise connately or naturally: if, as a result of these starting points given by nature, we form moral notions it seems appropriate for those

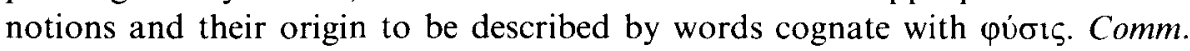
not $1070 \mathrm{c}-\mathrm{d}$ is particularly well illuminated by the theory of $\dot{\alpha} \varphi \rho_{0} \mu \alpha$ i. D.L. 7.89 (like Galen) draws a clear distinction between our internal propensity towards virtue and the influence of external factors, people, activities or things. It is hardly surprising therefore that in the Plutarch text our moral sense is said to have its origin from within.

But what is the connection between the dispositions towards virtuous behaviour and the moral notions themselves? After all, the question at issue is whether the Stoics considered moral notions not behaviour to be innate. Now, so far, we have shown only that the Stoics believed in inborn inclinations towards virtue. and that from our own resources we are disposed to favour certain patterns of behaviour. But if this is a theory of innateness, it is as yet only a theory of innate behaviour, when what we are supposed to be discussing is a theory of innate notions. To bridge this gap we would need a theory of behaviour according to which action presupposes beliefs and notions, so that if we are innately disposed to act in certain ways then we must be innately disposed to form the beliefs and notions necessary for that action. In the absence of such a theory, my appeal to the concept of $\dot{\alpha} \varphi \circ \rho \mu \eta \dot{~ m i g h t ~ s e e m ~ t o ~ b e ~ i r r e l e v a n t . ~}$

As it happens, the Stoics did embrace just such a theory of behaviour. According to them, if I follow some course of action, I assent to the proposition 'it is good to do $\mathrm{x}$ '. So innate $\alpha \hat{\varphi} \rho \rho \mu \alpha i$ towards certain patterns of behaviour automatically lead to and imply the formation of beliefs corresponding to this behaviour. If we have innate dispositions to do $\mathrm{x}$, then we have innate dispositions to believe that it is right to do $\mathrm{x}^{52}$

Furthermore, even if the Stoics did not have this theory of behaviour, there is still another way in which the innate $\hat{\alpha} \varphi \circ \rho \mu \alpha i$ imply innate dispositions to form ideas. One thing we have an innate disposition towards is the discovery of the $\kappa \alpha \theta \hat{n} \kappa o v$. So take an example of a Stoic $\kappa \alpha \theta \hat{\eta} \kappa o v$ - honouring your parents. ${ }^{53}$ According to the Stoics we are innately disposed or inclined to form the belief 
that it is right to honour one's parents, and so on for a whole list of $\kappa \alpha \theta i \operatorname{kov\tau \alpha .~If~}$ we are innately disposed to form these judgements, then presumably we are innately disposed to form the notions necessary for making those judgements. So both the beliefs and the notions will be innate in the Cartesian sense illustrated by the analogy of a congenital disease.

So what I am claiming for the Stoics is that, as a result of the $\alpha \varphi \circ \rho \mu \alpha i$ given to us by nature, we are disposed both to certain patterns of behaviour, and hence the formation of certain ethical ideas and beliefs. So in the terms of dispositional innatism these notions and beliefs are innate.

But what of Aëtius? Surely we can only get away with all this on pain of disregarding him completely. Not at all. What he says is entirely consistent with what many rationalists and innatists would say. As long as he is talking of the items in our mind of which we are aware, then it is an entirely reasonable - and uncontroversial - history of what follows what in the stocking of our minds: perception, memory, concept. It does not, in fact, tell us very much: are we more likely to inscribe this rather than that on the piece of paper? The most interesting thing about it is the active power it gives to the mind: it is this that does the writing - no mere passivity here. We should note that many innatists like More, Cudworth and Leibniz stressed the active power or sagacity of the mind. So the notion that the mind in this writing is influenced by aspects of its own nature to go for this rather than that is not ruled out.

Now compare the Stoic position with Lockean empiricism and you will see that the differences are quite stark. Locke would have protested vigorously at the Stoic claim that, for instance, we are naturally inclined to believe that it is right to honour one's parents, and he would have cited instances of parricides to make his case: there is no belief which we are innately disposed to form. This seems to me to distinguish the Stoics from Locke and to leave them hovering between dispositional innatism and an empiricism that believes not in bare capacities but in directed ones or in Quine's 'learning readiness' ${ }^{54}$ Furthermore, there is no doubt that the beliefs and notions which we have $\alpha \varphi \rho p \mu \alpha i$ to form are specific enough to ensure that the sort of dispositional innatism in question is not the trivial and uninteresting claim that the concept of pleasure, for instance, is innate.

In fact, I cannot imagine that the Stoics would have had any real quarrel with this position held by a well-known cleric in the eighteenth century:

That there are appetites and aversions, satisfactions and uneasinesses, inclinations and instincts, originally interwoven into our nature, must be allowed by all impartial and considerate men. It is I say evident that the Soul is so constituted, in her original state that certain dispositions and tendencies will not fail to shew themselves at proper periods and in certain circumstances; which affections are universal and not confined to any age or country, and not 
to be accounted for by custom or education, but alike in all humans at all times are properly said to be natural or innate.

Thus for example the fear of death and love of one's children are accounted natural, and the same may be said of divers other instincts and notions, such as the apprehension of a superior being, the abhorrence of many crimes and vices, the relish of things good and vertuous, which are to be looked on as natural inbred dispositions, resulting from the natural make of our minds, inasmuch as though they do not appear in our earliest infancy, yet in the growth and progress of the soul, they are sure to shoot forth and display themselves as naturally as leaves and blossoms do from a tree... .

The cleric in qustion is Bishop Berkeley, preaching on 'The Will Of God' a few months before his death. ${ }^{55}$

\section{(5) Did the Stoics use innatism for epistemological purposes?}

Now that we have connected some evidence about the formation of moral notions with our analysis of innatism above, ${ }^{56} \mathrm{I}$ hope it has become clear that the Stoics can safely be described as dispositional innatists. Furthermore, in saying this, I do not have to ignore the well-attested empiricist leanings of the Stoa: adventitious concepts, for instance of colours, owe their origin to direct confrontation with our environment; and even though moral concepts have an intrinsic source, sense-experience will play a crucial rôle in developing them. This is made clear in Seneca, Ep. Mor. 120, where, after saying that nature gives us a head start in learning virtue, he emphasizes that the work that we have to put in involves making analogies based upon repeated observations. Innatism and empiricism can co-exist quite happily in the Stoa.

Now the point of saying that the Stoics were empiricists is that they thought our observations could justify certain beliefs, and this reminds us that our task of showing that they were also innatists is not yet finished, because, in addition to distinguishing dispositionalism from other forms of innateness, I referred to a more basic distinction between the uses to which these different types of innateness could be put, that is between psychological innatism, a theory that confines itself to making claims about the origin of our ideas and beliefs, and epistemological innatism which attempts to show that certain beliefs, which are innate, should command our respect. ${ }^{57}$ As yet, I have only brought out the psychological aspect of Stoic innatism which consists in the claim that we are naturally disposed to form certain beliefs regardless of what experience we have. What we need to show now is that just as claims about our environment can be justified by sense-observations, the Stoics expected moral beliefs to be trustworthy because they derive from innate dispositions. 
It is not in fact difficult to see that the Stoics went beyond psychological innatism and claimed that the moral rules that arise naturally are the ones we should follow. When Diogenes mentions our $\dot{\alpha} \varphi$ op $\mu \alpha i$ in 7.89 he says that these inclinations that nature gives us are not perverse. If one asks why the Stoics should think this, the answer lies, of course, in their view that nature is providential. Our inclinations, like our senses, must be trustworthy because they are given to us by Nature, and Nature, after all, is nothing if not good..$^{58}$

This line of argument is very similar to the theological support that some of Locke's opponents claimed for their arguments: a benign God would hardly give us perverted ideas or inclinations to form ideas. This similarity becomes even clearer when we remember that for the Stoics Nature and God are equivalent, ${ }^{59}$ and when we come to Epictetus we frequently see him talking of the natural resources (i.e. perception and prolepses) that God has given us. ${ }^{60}$

There is, however, another way of showing why the Stoics' innate dispositions could not have been perverse. In Galen and as well as in a crop of other texts, ${ }^{61}$ the Stoics emphasize that evil cannot be natural to us; perversity must result from things extrinsic to us. The reason they insisted on this must have a great deal to do with the fact that they thought that all men are parts of universal nature, or fragments of it $(\dot{\alpha} \pi \sigma \sigma \pi \dot{\alpha} \sigma \mu \alpha \tau \alpha){ }^{62}$ They also thought that virtue consisted in living in accordance with universal nature, ${ }^{63}$ and so if they thought that these offshoots are endowed with innate tendencies at all, it is far more plausible that these off-shoots are disposed towards rather than against the whole, that is disposed to virtue rather than vice. Thus for the Stoics, the claim that a disposition to form an idea is natural to man does automatically guarantee justification. For other innatists this guarantee may only be inspired by a pious and rather feeble hope; for the Stoics it is the patural implication of their physical views.

Perhaps we can take this appeal to Stoic physics further and argue that it does not so much show that, if they were innatists, they were of the epistemological variety, but that they were innatists. For if we are off-shoots of universal nature, it is more likely that we are inclined towards fitting in with it than that we are moral tabulae rasae, that is utterly indifferent as to whether we are at one with the whole or alienated from it. The Stoics, on this view, are naturally inclined to innatism. ${ }^{64}$

CLARE COLLEGE, CAMBRIDGE

DOMINIC SCOTT

\section{NOTES}

1. G. W. Leibniz, New essays on human understanding, preface 48-9 (trans. P. Remnant \& J. Bennett).

2. Aëtius Plac. 4.1 = Stoicorum Veterum Fragmenta (SVF) I. 83, 11.13-23. The Greek text is quoted below on p.136. 
3. Plutarch, De communibus notitiis $1070 \mathrm{c}$ d. For the Greek text see below p.137. I discuss this translation in $n .36$ below.

4. Meno 85d9-86b4. For some reasons for taking recollection very literally in the Phaedo see my 'Platonic anamnesis revisited' $C Q 37$ (1987) 355.

5. Meno $82 \mathrm{~b} 9-5 \mathrm{~d} 4$.

6. Phaedo $74 \mathrm{a} 9-5 \mathrm{~b} 2$.

7. For a statement of this criticism see D. Gallop, Plato's Phaedo (1975) 132.

8. See N. Jolley, Leibniz and Locke (1984) 167; J. Barnes, 'Mr Locke's darling notion', PQ 22 (1972) 193; R. I. Aaron, John Locke ed.3 (1971) 94.

9. Locke, Essay $B k 1.2 \S 5$.

10. Locke's strategy is clearly set out by Jolley (1984) 170. Recently, Nelson Goodman has exhumed the point of $1.2 \$ 5$ in 'The epistemological argument' reprinted in $\mathrm{H}$. Morrick (ed.), Challenges to empiricism (1980) 255-6.

11. That he singled out this portion of Locke's attack and devoted such a large amount of space to it is an indication of its importance in the debate. It is worth noting that Locke's $2 \S 5$ has the longest of the replies in Leibniz's Bk 1.

12. Leibniz, New essays 1.1.78.

13. Leibniz seems to recognize his relationship to Platonic recollection at N.E. Preface, p. 52, 1.1.789, and 1.3.106. See also Discourse on Metaphysics 26.

I should point out that Leibniz's theory of implicit knowledge is by no means the only type of innateness he espouses: this is in fact only one strand out of the very complex account of innatism that he gives in the New essays. Some scholars have listed several different types of innateness in Leibniz. (See, for instance, A. Savile, 'Leibniz's contribution to the theory of innate ideas', Philosophy 47 (1972) 113-24; Jolley (n.8) 171-8. Among these is the theory of innate dispositions that 1 discuss below. See also n.25 below.

14. Among the Cambridge Platonists, More and Cudworth embraced dispositionalism and often took some care to reject claims that we are born with any actual knowledge. See, for instance, More's Antidote against atheisme $1.5 \$ 2$. Descartes made similar qualifications to innatism. See next note.

15. Descartes Notes against a certain programme (trans. Haldane \& Ross) vol. I (1984) 442.

16. Locke, Essay $1.3 \S 9$.

17. For this criticism of Locke see Jolley (n.8) 171.

18. One such philosopher seems to have been Locke's most forthright opponent, Bishop Stillingfleet, who is discussed by Yolton, John Locke and the way of ideas (1956) 36-8.

19. Meno $97 \mathrm{a} 34$. 
20. This would be to follow Meno's example of mouthing the pronouncements of his mentor Gorgias. In the first few pages of the Meno Plato uses a number of references to Gorgias to underline Meno's shortcomings in this respect. At first, Socrates seems to make out that discovering the definition of virtue is a question of recollecting what Gorgias has said on the matter $(70 \mathrm{c} 10 \mathrm{dl})$; he asks Meno to perform this task of recollection, but then generously adds that Meno can say what he himself thinks (as he will no doubt agree with Gorgias). After Meno's first downfall, Socrates asks him again to recollect what Gorgias said (73c6-8), hastily adding a terse kai $\sigma u$ to imply that this will be Meno's own view. At 76bl, however, Meno is getting closer to áropi $\alpha$ and Socrates asks him for a third time to remember what Gorgias has said, though now without pretending that Meno has worked things out for himself. Soon, of course, we shall see that the discovery of the definition will involve a rather different kind of recollection. See also $76 \mathrm{c} 4$

21. See above, p.126.

22. W. V. O. Quine, 'Natural kinds', in Ontological relativity and other essays (1969) 123.

23. W. V. O. Quine, Word and object (1960) 83.

24. W. V. O. Quine, 'Linguistics and philosophy' in S. Hook (ed.), Language and philosophy 96.

For Chomsky's reaction to Quine, see 'Quine's empirical assumptions' in D. Davidson \& J. Hintikka (eds.), Words and objections: essays on the work of W. V.O Quine (1969) 53-68, esp. 54-5; Reflections on language $198 \mathrm{ff}$.

25. Leibniz is here showing his dispositionalist tendencies as an innatist. Dispositionalism seems to co-exist alongside his theory of implicit or unconscious knowledge in Bk 1 of the New essays. In such dispositionalist moods Leibniz invokes the analogy of a veined block of marble: learning is not like carving a Hercules out of any old block of marble, but out of one whose veins naturally follow the shape of Hercules. Leibniz dismisses the tabula rasa because it allows anything to be written on it. His tabula would be such as to favour a certain message. See Preface 52, and Bk 1.1.80, where he talks of the mind having special affinities, dispositions, aptitudes and pre-formations, and 86 , where he mentions potentialities and tendencies. All these he opposes to a bare passive faculty. For an interpretation which claims that for Leibniz dispositinalism in fact reduces to implicit or unconscious knowledge see C. D. Broad, Leibniz: an introduction (1975) 134-5, and N. Jolley, 'Leibniz and Malebranche on innate ideas', $P R 97$ No. 1 (1988) 86-7.

26. See Barnes, (n.8) 211-12; 1. Hacking, Why does linguistics matter to philosophy? (1975) 57; Jolley (n.8) 167 and 179, where he connects the dispute about innatism with one about materialism.

27. Leibniz, New essays, preface 49; see Hacking (n.26) 63.

28. See Descartes' third Meditation and the first book of More's Antidote against atheisme.

29. For a discussion of the strong moral motivation behind the doctrine of innate ideas see Yolton (n.18) 28-35.

30. This objection was made in 1666 by Samuel Parker in A free and impartial censure of the Platonick philosophy, 55.

31. This is More's approach at the beginning of his Antidote against atheisme. In a later edition of the same work he included an appendix in which he expressly denied that he had argued from the innateness of our ideas to their reliability; rather, it is the naturalness of certain ideas, whether they are 
innate or not. See H. More, A Collection of several philosophical writings (1662), Appendix to the Antidote against atheisme it $\$ 1-3$.

32. For this approach see, for instance, Herbert of Cherbury De Veritate (Locke's only named opponent on the issue of innate ideas) (trans. Meyrick H. Carré) 126.

33. To revert to Platonic apologetics: the epistemological impotence of psychological innatism rules it out as a reasonable alternative to anamnesis. Because Plato was attempting to solve an epistemological problem when he first proposed anamnesis, he could have no interest in dispositional innatism as a purely psychological thesis: he would have wanted to see how it could account for full-blooded knowledge. So merely to say that he should have taken up dispositional innatism misses the point. In Locke's day the obvious way to supplement the psychological thesis was to appeal to God. Plato does not avail himself of God, and so without Him would ask where the innate knowledge comes from. The answer is that it cannot come into being (any more than God's knowledge does); so an eternally pre-existent soul is a perfectly logical solution, and one necessary to solve the problem that he has raised (see Meno 85d12ff.). If the charge is that Plato should have invoked God, at least he can no longer be accused of greater metaphysical extravagance than some of his successors. At any rate, it is amply clear by now that Plato was a wishful thinker, not in the sense that he wished the soul to be immortal but that he wished it to know. (I am grateful to Myles Burnyeat for suggesting this line of argument.)

34. The debate over whether the Stoics believed in innate moral notions is long-lived. Among those who advocate an innatist interpretation are A. Bonhöffer (Epictet und die Stoa (I890) 199 207) and E. Grumach ('Physis und Agathon in der alten Stoa', Problemata 6 (1932) 72 6). Bonhöffer argued that Stoic prolepses were seminal moral concepts whose origin owed nothing to sensation; he was then taken to task by F. H. Sandbach in his influential article 'Ennoia and prolepsis' (reprinted in A. A. Long (ed.), Problems in Stoicism (1971) 23-37). J. M. Rist (Stoic Philosophy (1969) 134), J. B. Gould (The philosophy of Chrysippus (1970) 64 n.2) and R. B. Todd ('The Stoic common notions', Symbolae Osloenses 48 (1973) 53ff.) have sided with Sandbach's strongly empiricist interpretation, while earlier M. Pohlenz had advocated a middle path, though still rejecting any theory of innate a priori knowledge (Grundfragen der stoischen Philosophie (1940) 82-99, esp. 96, and Die Stoa ed.2 (1969) I 56-

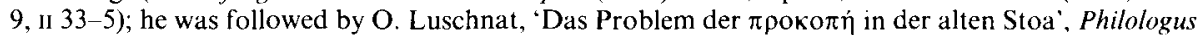
(1958) 191-2). Other scholars who are more sympathetic to the innatist cause. or who at least feel uneasy with Sandbach's position are G. Watson (review of Gould in $P Q 22$ (1972) 268 9) and T. Irwin ('Aristotelian and Stoic conceptions of happiness' in M. Schofield \& G. Striker (eds.). The norms of nature (1986) 208-9 with n.5).

35. See above p.123.

36. When I translated this sentence on p. 124 above I took $\tau \alpha \hat{v} \tau \alpha$ ('the former') to refer not to the good

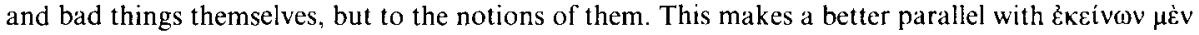
... ai pavtaría and means that we do not have to attribute to the Stoa the view that both good and evil proceed from within the soul; this would contradict the point of Galen's De placitis Hippocratis et Platonis 5.5 and Diogenes Laërtius 7.89 (among others) which I discuss below. See pp. 142ff.

Also, I am accepting $\dot{\alpha} \rho \chi \hat{\omega} v$ as an emendation of $\dot{\alpha} \gamma \alpha \theta \hat{\omega} v$, which makes very little sense in the context. This emendation has been proposed by A.J. Kronenberg ("Ad Plutarchis Moralia", Mnemosyne (1924) 105-6). As an alternative emendation of $\dot{\alpha} \gamma \alpha \theta \hat{\omega} v$, Pohlenz has suggested $\dot{\alpha} \varphi \circ \rho \mu \hat{\omega} v$ (Die Stoa II 34). This would be very tempting in the light of what I say below.

37. The word $\dot{\varepsilon} \pi \varepsilon ı \sigma o \dot{\delta} t o \zeta$ is used in a context very relevant to ours in a fragment of Plutarch describing Plato's theory of recollection (Plutarch Moralia vol. 15 (Loeb) 388 -9). In contrast to the innate knowledge within us, Plutarch talks of $\tau \hat{\omega} v \alpha \lambda \lambda \lambda \omega v \varepsilon \pi \varepsilon i \sigma o \delta i \omega v$, presumably referring to the incoming data of sense-perception. For a discussion of this fragment see my 'Platonic anamnesis revisited' (n.4) 349 with n. 10. 
38. Sandbach ((n.34) 28) has difficulties with this piece of evidence, and ends up describing

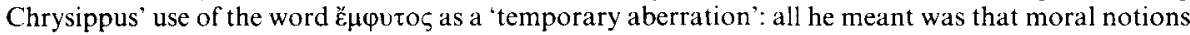
come to us without training, not that they pre-exist experience. As Watson ((n.34) 268-9) has pointed out, this state of affairs is unsatisfactory. In effect, Sandbach's case rests in part on discarding one piece of evidence, which is exactly what he accuses Bonhöffer of doing with Aëtius. Anyway, why should we assume that Plutarch, or worse still Chrysippus, is at fault?

39. A note of warning should be sounded about using this text as a checklist of prolepses, as a number of scholars have done. What is under discussion is the formation of conceptions (voou $\mu \varepsilon v \omega v$ ), which the Loeb translation happily renders as 'general notions'. This is fine for the first items on the list, notions of sensible things, but the next example, thinking of Socrates, is obviously concerned with a

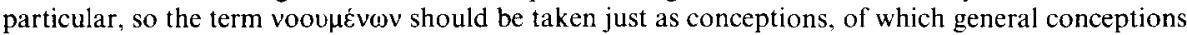
are a species. Another reason this chapter cannot be about prolepses alone is that most of the examples - pygmies, handless men and the like - could hardly be criteria of truth, as prolepses are meant to be. So the chapter is about conceptions in general, some of which are scientific, such as the example of analogy (the centre of the earth).

When we come to the formation of the conceptions good and just, the qualification $\tau l$, which has been missing from all the other examples, is added. This qualification could be interpreted in two ways. Either he means that a particular thing is thought to be good, in which case this example joins the Socrates case, or he is talking about the formation of a hazy general notion. Though these may seem very different interpretations, I do not think that it matters too much which one we take, because involved in the formation of a notion of a good thing will be some sort of general notion of goodness, which is not very developed. For a discussion of the qualification $\tau$ see Bonhöffer (n.34) 200 and Sandbach, (n.34) 33-4.

\section{Bonhöffer (n.34) 204}

41. Sandbach ((n.34) 29) recognizes the importance of this task and originally attempted to explain $\varphi v \sigma ı \hat{\omega} \zeta$ by reference to Cicero's De Finibus 3.33-4, where it is claimed that we gain an understanding of the good by a process of analogy - the mind ascends by inference from things in accordance with nature, and so reaches the good: but, in the end, it does so not by comparison, but recognizes the good 'propria vi sua'. Sandbach translates this as 'by the force of its own nature', saying that this explains the adverb in Diogenes Laertius 53. But, as he himself pointed out in the postscript to his article, this explanation is unsatisfactory: Cicero is not making a point about the naturalness of our learning, but about the nature of what is learnt ((n.34) 33). Another problem with Sandbach's explanation is that it does not show how the notion of justice is formed: he appeals to no text parallel to the one by Cicero.

\section{Pohlenz, Grundfragen 96, see also 88; Die Stoa 58 (see n.34).}

\section{O. Luschnat, Philologus (1958) 191-2.}

44. A third problem is one that has been pointed out by Sandbach who, in the post-script to his article 'Ennoia and prolepsis' (n.34), criticizes Pohlenz's case because he only tries to show how the concept of good comes naturally and neglects to do the same for justice which D.L. 7.53 also mentions.

This problem can be alleviated somewhat by a passage from Porphyry's De Abstinentia in which we

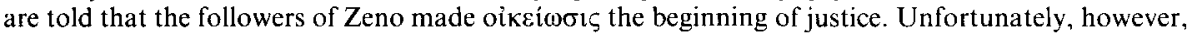
this rather vague statement is not further explained. As S. G. Pembroke points out ('Oikeiosis' in

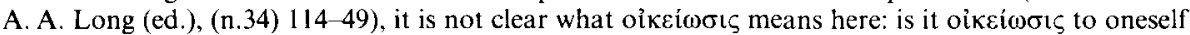
or to one's children, or what? Is it a peculiarly human form of oiksi $\omega \sigma \mathrm{\iota} \zeta$, or does it apply to all animals? Because Porphyry is arguing for vegetarianism, he himself holds that justice and injustice apply to animals as well as men, but he could be perverting a Stoic doctrine for his own ends. In the next chapter, Porphyry launches into a bitterly sarcastic attack on Chrysippus, so his representations of Stoic doctrine may be none too careful. Also, we do not know who exactly held the doctrine - 
perhaps not Zeno himself, though it is reasonable to think that Chrysippus can be included among his followers.

Nevertheless, this passage does suggest a case of an innate disposition giving rise to justice. What exactly that innate disposition is does not affect our issue which is whether or not the formation of concepts is entirely dependent upon sense experience. On this see also the Anonymous commentator on Plato's Theaetetus col. 5-6 where he discusses the view - presumbaly Stoic - that we have

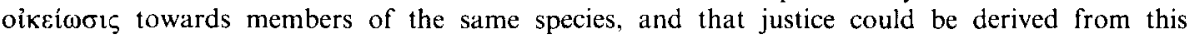

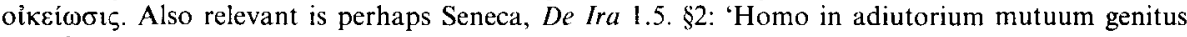
est ....

45. T. Irwin (n.34) $208-9$ with n.5.

46. Galen, De Plac. Hip. et Plat. 5.5.1-15. See also SVF 111. 230-6.

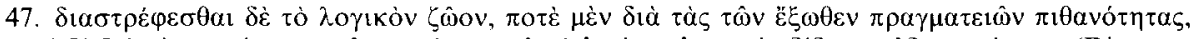

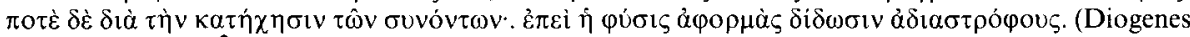
Laërtius 7.89)

48. See s.v. esp. 3,4 .

49. Diogenes Laërtius 7.76.

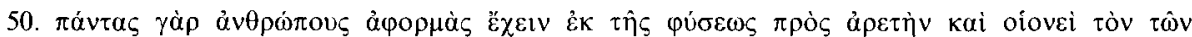

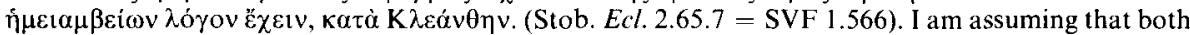

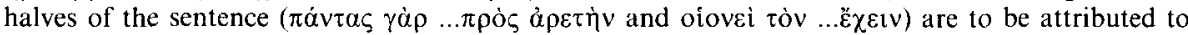
Cleanthes: without the first half, the second would be Delphic in the extreme

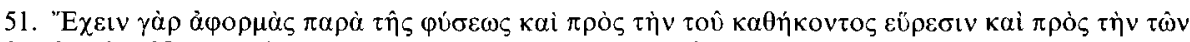

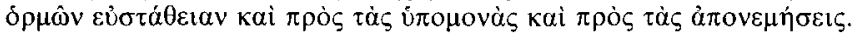

One scholar, A. Grilli (Il problema della vita contemplativa (1953) $116 \mathrm{n} .1$ ), has attempted to argue that neither from this evidence nor from Stob. 2.65 .7 nor from D. L. 7.89 can we claim that the early Stoa used the word $\alpha \varphi \circ \rho \mu \eta े$ to mean 'starting-point' or 'inclination'; this use only seeped into the Stoa with Panaetius who advocated a life lived 'in accordance with the $\alpha \varphi \rho \rho \mu \alpha i$ given to us by Nature' (fr. 96 van Straaten). In the case of the Cleanthes citation Grilli adopts a punctuation that attributes only

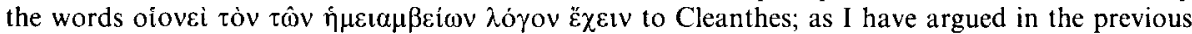
note, this is implausible. As for Diogenes Laërtius 7.89 , Grilli accepts that the thought expessed is Chrysippus' (because of Galen's testimony in Plac. Hip. et Plat. 5.5) but he still denies that the term $\dot{\alpha} \varphi \rho \rho \mu \eta \dot{~ c a n ~ b e ~ a t t r i b u t e d ~ t o ~ a n y o n e ~ e a r l i e r ~ t h a n ~ P a n a e t i u s . ~ H i s ~ a r g u m e n t ~ i s ~ t h a t ~ a s ~ b o t h ~ S t o b a e u s ~}$ and Diogenes are influenced by Panaetius (via Hecato) their use of the word ò $\varphi \circ \mu n$ ń could easily be a product of this influence. But this is made implausible by the fact that, as he himself admits, 'starting-

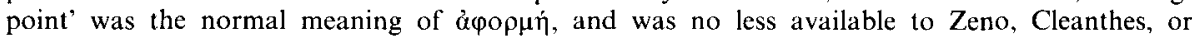
Chrysippus, than it was to Panaetius.

52. The evidence for this comes from Plut. Comm. not. 1057a.

53. My example is culled from Diogenes Laërtius 7.108.

54. See above p.133.

55. This passage is quoted by Barnes ( (n.8) 207) who points out that the innatism espoused here seems to have by-passed Berkeley's best-known works. 
56. See above Varieties of innatism, 125-35.

57. See above pp.135-6.

58. Nature's providence in endowing us with sense-perception is implied by Sext. Adv. math. 7.259-60 and Cic. Ac. 1.42. An interesting parallel can be found in Sext. Adv. math. 8.276, where the Stoics are said to have argued that the existence of signs can be inferred from the fact that the notion of the sign is part of the natural constitution of man.

59. Cic. De Nat. Deorum 1.39.

60. Epictetus talks of God-given prolepses in Diss. 3.5.8. Interestingly enough, in the same passage he talks of these prolepses as $\dot{\alpha} \varphi \rho_{\mu} \alpha \dot{\alpha}$. But for Epictetus, $\dot{\alpha} \varphi \circ \rho \mu \eta \dot{\eta}$, when used in these contexts, has a rather general meaning: it applies not only to prolepses but also to perception (see also 4.10.14).

61. SVF III. $229-36$.

62. D.L. 7.87 and 143 .

63. Stob. Ecl. 2.75.11-76,8; D.L. 7.87-9.

64. I am very grateful to Margaret Atkins, Myles Burnyeat, Malcolm Schofield, David Sedley and Robert Wardy for their comments on various drafts of this paper. I have also benefited from a characteristically spikey interrogation by the Cambridge B Club and, more recently, from the editorial hustling of M. M. Mackenzie. 